\title{
Differential expression of two pro-opiomelanocortin mRNAs during temperature stress in common carp (Cyprinus carpio L.)
}

\author{
R J Arends, R van der Gaag, G J M Martens, S E Wendelaar \\ Bonga and G Flik
}

Department of Animal Physiology, University of Nijmegen, Toernooiveld 1, 6525 ED Nijmegen, The Netherlands

(Requests for offprints should be addressed to R J Arends)

\begin{abstract}
Pro-opiomelanocortin (POMC) is the precursor of a number of biologically active peptides, including adrenocorticotropic hormone, $\alpha$-melanocyte-stimulating hormone and $\beta$-endorphin, which are released by the pituitary glands of fish as well as mammals. To quantify the levels of expression of the two POMC mRNAs relative to one another during the response of the common carp to temperature-induced stress, we used reverse transcriptase PCR combined with capillary electrophoresis and laserinduced fluorescence detection. The ratio of POMC-I mRNA to POMC-II mRNA determined in wild-type and four isogenic carp strains was found to be straindependent and influenced by temperature. In strain
\end{abstract}

E20 $\times \mathrm{R} 8$, the ratio had altered in favour of POMC-I from 1:3.2 (POMC-I:POMC-II) in fish adapted to $24^{\circ} \mathrm{C}$ to $1: 1 \cdot 2$ in fish adapted to a decrease of $9{ }^{\circ} \mathrm{C}$ in ambient temperature. A rapid drop in temperature from 24 to $15{ }^{\circ} \mathrm{C}$ decreased the POMC mRNA ratio at the expense of POMC-I from $1: 1.9$ in the control fish (strain $\mathrm{E} 4 \times \mathrm{R} 3 \mathrm{R} 8$ ) to $1: 4 \cdot 23 \mathrm{~h}$ after the temperature drop of $9{ }^{\circ} \mathrm{C}$. We conclude that both POMC genes are expressed in the common carp and that their expression ratio is strain-dependent and changes in response to ambient temperature.

Journal of Endocrinology (1998) 159, 85-92

\section{Introduction}

In fish, stressors activate the hypothalamic-pituitaryinterrenal system, and the subsequent increased release of pro-opiomelanocortin (POMC)-derived peptides from the pituitary gland induces cortisol release from the corticosteroid-producing cells of the head kidney. A variety of external stimuli is known to induce a stress response in fish (for a review, see Wendelaar Bonga 1997). The common carp is a rather stenohaline fish (Gupta \& Hanke 1982), and changes in water salinity increase plasma cortisol levels (Abo \& Hanke 1984) which points to a stress response. In euryhaline teleosts also such as the Mozambique tilapia (Oreochromis mossambicus) (Balm et al. 1994) and the sea bream (Sparus aurata) (Mancera et al. 1994), rapid salinity changes can act as stressors. Moreover, stressors may also affect the integrity of the branchial epithelium, thereby increasing stress (Ultsch et al. 1981).

POMC is the precursor of the hormones adrenocorticotropic hormone (ACTH), $\alpha$-melanocyte-stimulating hormone $(\alpha-\mathrm{MSH})$ and $\beta$-endorphin in all vertebrate classes. Genome duplication in the common carp resulted in a tetraploid animal (Uyeno \& Smith 1972). In the common carp, the duplicate loci started to diverge from each other only some 16 million years ago (Larhammar \&
Risinger 1993). For this carp two POMC cDNAs (POMC-I and POMC-II) have been cloned; as the two POMC molecules show substitutions in their $\beta-\mathrm{MSH}$ and corticotropin-like intermediate peptide (CLIP) regions, different POMC end products with specific functions may be expected (Arends et al. 1998). The expression of two POMCs in tetraploid animals has been known for many years (Kawauchi 1983, Martens et al. 1985, Salbert et al. 1992), but there is as yet little evidence for the biological significance of the presence of two gene transcripts. Furthermore, no method for discriminating between the two hormone precursors at the mRNA level has been published.

We report here on the quantification of the two closely related carp POMC mRNAs. PCR, a sensitive method of quantifying mRNA expression (Murphy et al. 1990, Siebert \& Larrick 1993), was combined with capillary electrophoresis (CE) and laser-induced fluorescence detection (LIF) (Fasco et al. 1995).

Changes in ambient temperature affect all kinds of biological processes. For carp it has been demonstrated that an increase in water temperature stimulates the basal release of pituitary gonadotropins (Lin et al. 1996); growth is also enhanced with rising temperature (Fine et al. 1996). In addition, low environmental temperatures have been 
shown to affect the immune system and suppress specific immune functions in carp (Le Morvan-Rocher et al. 1995, Won \& Lin 1995). Whether changes in ambient temperature can activate the hypothalamic-pituitary-interrenal system and evoke a stress reponse in carp is not known. In the present study we quantified the expression of the two POMC mRNAs in different strains of isogenic carp, in response to sustained changes in ambient temperature and to a rapid fall in temperature.

\section{Materials and Methods}

Adult male and female carp, Cyprinus carpio L., weighing around $100 \mathrm{~g}$, were obtained from the central fish culture facility ('de Haar vissen') of the Agricultural University of Wageningen, The Netherlands. The isogenic carp strains used for the experiments were E4, E4 $\times \mathrm{R} 3 \mathrm{R} 8$, E20 $\times$ R 8 and R3 $\times$ R8; wild-type carp from our laboratory stock were also used (Bongers et al. 1997). The fish were held in 100 litre tanks with circulating, filtered and well-aerated tapwater at $24^{\circ} \mathrm{C}$ and a photoperiod of $16 \mathrm{~h}$ light alternating with $8 \mathrm{~h}$ darkness. The fish were fed commercial fish food (Trouvit; Trouw, Putten, The Netherlands), at a ration of $1.5 \%$ of the body weight per day.

For CE, a P/ACE 5010 unit equipped with a 635 laser module and a double-stranded DNA 1000 coated capillary $(47 \mathrm{~cm} \times 100 \mu \mathrm{m}$; Beckman Instruments, Fullerton, CA, USA) was used. Restriction enzymes were from Boehringer-Mannheim (Mannheim, Germany), reagents for reverse transcriptase (RT)-PCR from Gibco-BRL (Grand Island, NY, USA), and primers from Biolegio (Malden, The Netherlands). DNA intercalators TOPRO-3 and TOTO-3 for CE were from Molecular Probes Inc. (Eugene, OR, USA) and all other chemicals were from Pharmacia (Uppsala, Sweden). Sterilization filters $(0 \cdot 45 \mu \mathrm{m})$ were from Amicon (Danvers, MA, USA).

\section{$R T-P C R$}

RNA from pituitary glands was isolated according to the Gibco-BRL RNAzol protocol. Total RNA (5 $\mu \mathrm{g}$ in 100\% ethanol) was precipitated, washed in 70\% ethanol and air-dried. The pellet was dissolved in $15 \mu \mathrm{l}$ double distilled water and $0.7 \mu l 5^{\prime}-\mathrm{pd}(\mathrm{N})_{6}$ random hexamer oligonucleotide primer $(10 \mu \mathrm{g} / \mu \mathrm{l})$, incubated for $10 \mathrm{~min}$ at $65^{\circ} \mathrm{C}$, spun for $5 \mathrm{~s}$ and put on ice. Then $3 \mu \mathrm{l} 0 \cdot 1 \mathrm{M}$ dithiothreitol, $1.5 \mu \mathrm{l} 10 \mathrm{mM}$ dNTPs, $7.5 \mu \mathrm{l} 5 \times \mathrm{RT}$ buffer and $0.5 \mu \mathrm{l}$ RNA inhibitor $(20 \mathrm{U})$ were added. After incubation for $15 \mathrm{~min}$ at $65^{\circ} \mathrm{C}, 0.5 \mu \mathrm{l}$ RT-Superscript $(100 \mathrm{U})$ was added and the mixture incubated for $60 \mathrm{~min}$ at $42{ }^{\circ} \mathrm{C}$.

The primers used for PCR were: 5' CA GAA TTC CTA TGC AGG TCT GAT CTG 3' CCCAP (forward) and 5 ' TC CTC GAG TGC TCT TTG TTT ATG ACG TTT 3' CCCAP (reverse).
Template DNA (2.5 $\mu \mathrm{l}$ RT-mix) and 50 pmol of each primer were used in a final volume of $40 \mu \mathrm{l}$ containing $1 \times$ PCR buffer (Gibco), $1.5 \mathrm{mM} \quad \mathrm{MgCl}_{2}, \quad 375 \mu \mathrm{M}$ dNTPs and 1 unit Taq DNA polymerase. After an initial denaturing step at $94{ }^{\circ} \mathrm{C}$ for $5 \mathrm{~min}$, the subsequent cycles consisted of denaturing at $94{ }^{\circ} \mathrm{C}$ for $1 \mathrm{~min}$, annealing at $51{ }^{\circ} \mathrm{C}$ for $1 \mathrm{~min}$, and elongation at $72{ }^{\circ} \mathrm{C}$ for $1 \mathrm{~min}$ for 30 cycles. A final elongation step was carried out at $72{ }^{\circ} \mathrm{C}$ for $10 \mathrm{~min}$.

After PCR amplification, $5 \mu \mathrm{l}$ PCR-mix was digested in a final volume of $15 \mu \mathrm{l}$ containing $1 \times$ Sure cut buffer $A+M(1: 1)$ and 10 units restriction enzyme SacI, PvuII or both at $37^{\circ} \mathrm{C}$ for $3 \mathrm{~h}$. Two POMC mRNAs, POMC-I and POMC-II, were co-expressed in the pituitary gland of all carp studied. RT-PCR for detection of POMC in the pituitary gland resulted in a $515 \mathrm{bp}$ product, in accordance with the primer set chosen. Proceeding from the sequence analysis of the two POMC cDNAs, PvuII was chosen to specifically digest POMC-I into two products of 227 and $288 \mathrm{bp}$, and SacI for digestion of POMC-II into two products of 171 and $344 \mathrm{bp}$ respectively. It should be noted that the $515 \mathrm{bp}$ band in lane s (see Fig. 1) contains POMC-I and possibly SacI-undigested POMC-II, and the $515 \mathrm{bp}$ band in lane $\mathrm{p}$ contains POMC-II and possibly PvuII-undigested POMC-I. A small amount of undigested product POMC-I, POMC-II, or both was possibly present in lane $\mathrm{p} / \mathrm{s}$ (515 bp band, Fig. 1).

In the RT-PCR the two POMC mRNAs were amplified by a single primer set. The ratio between the two POMC mRNAs was assessed using different numbers of PCR cycles in two strains, wild-type and E4 $\times$ R3R 8 . The ratio in wild-type and $\mathrm{E} 4 \times \mathrm{R} 3 \mathrm{R} 8$ carp proved to be independent of the number of PCR cycles. The POMC-I:POMC-II mRNA ratio was dependent on the strain used (see Fig. 2). The amount of RT-mix as template $(3-17 \%$ of the total RT-mix) in the PCR was tested, and the POMC ratio was found to be independent of the amount of template (data not shown).

\section{Capillary electrophoresis}

The wash buffer was TBE $(89 \mathrm{mM}$ Tris, $89 \mathrm{mM}$ boric acid, 2 mM EDTA, pH 8.5) containing 50 nM TOTO-3 or TO-PRO-3. Separation medium contained 3\% acrylamide, $0 \cdot 04 \%$ ammonium persulphate and $0 \cdot 1 \%$ $N, N, N^{\prime}, N^{\prime}$-tetramethylethylenediamine in wash buffer and was allowed to polymerize overnight at $4{ }^{\circ} \mathrm{C}$. Buffers were filtered through a $0.45 \mu \mathrm{m}$ sterilization filter before use. The column was high-pressure-washed in the reverse direction with fresh separation buffer for $5 \mathrm{~min}$ before each injection. Before injection of the sample, the capillary was loaded with TO-PRO-3 or TOTO-3 in wash buffer with high pressure for $12 \mathrm{~s}$; next the sample was applied by either $25 \mathrm{~s}$ pressure loading or $60 \mathrm{~s}$ electrokinetic loading at $7 \cdot 4 \mathrm{kV}$. Electrophoresis was performed at $200 \mathrm{~V} / \mathrm{cm}$, using a reversed polarity and separation medium. 
CE-LIF was used to quantify the PCR products. Integrated peaks corrected for retention times were calculated using Beckman 'GOLD' version 8.10 software. The sum of the integrated peak areas represents the amount of PCR product (see Fig. 3). The sum of the peak areas 2, 3, 4 and 5 represents the two POMC mRNAs and is designated 100\%. Peaks 3 and 4 represent POMC-I and peaks 2 and 5 POMC-II. The POMC-I:POMC-II ratio was calculated by taking the ratio of the integrated peaks of POMC-I (peak 3 and 4) and POMC-II (peak 2 and 5). Primers for PCR appeared in peak 1 and the undigested fraction in peak 6; the latter was always less than $7 \%$. CE-LIF analysis indicated that under the conditions chosen (30 PCR cycles and $3 \mathrm{~h}$ digestion by the restriction enzymes), the mean \pm s.E.M. digestion of POMC cDNAs was $97 \cdot 0 \pm 0 \cdot 4 \% .(n=61)$.

\section{Temperature-induced stress}

Strain E4 $\times$ R3R8 fish were kept in groups of 10 in 100 litre tanks $(n=16)$. Each tank represented one experimental group. Eight groups were used as controls for each time point, and another eight groups were temperatureshocked by exposure to a $9^{\circ} \mathrm{C}$ reduction in ambient temperature. The circulating water at $24^{\circ} \mathrm{C}$ was changed by a flow through of water at $15^{\circ} \mathrm{C}$. Within $45 \mathrm{~min}$ the ambient temperature in the tank decreased from 24 to $15{ }^{\circ} \mathrm{C}$. At time point $t=0$, one control and one experimental group were netted in one scoop using a net fitted to the aquarium. Fish were anesthetized in $0.3 \mathrm{~g} / 1$ tetramethylsilane (Sigma, St Louis, MO, USA) and $0.6 \mathrm{~g} / 1$ bicarbonate, and blood samples were taken within $5 \mathrm{~min}$ of capture (Weijts et al. 1997). This procedure allowed detection of basal cortisol levels in this species. After blood sampling, the fish were decapitated, and the pituitary glands removed and stored at $-20{ }^{\circ} \mathrm{C}$. The temperature shock treatment started at $t=0$ : the temperature (in the eight experimental tanks) was decreased within $45 \mathrm{~min}$ from 24 to $15^{\circ} \mathrm{C}$ as described above, without handling of the fish. At time points 20, 40, 60, 90 and $180 \mathrm{~min}$, one control and one experimental group were netted and sampled as described above. At $3 \mathrm{~h}$ after the onset of the temperature shock treatment, the temperature was increased again and within $45 \mathrm{~min}$ had reached $24^{\circ} \mathrm{C}$. At $t=300 \mathrm{~min}$, the last control and experimental groups were sampled.

In a separate experiment, long-term acclimation effects on POMC mRNA expression were studied. Three groups (strain E20 $\times$ R8, weight about $50 \mathrm{~g}$ ) were adapted for 8 weeks to different environmental temperatures of 15,24 or $29^{\circ} \mathrm{C}$. After 8 weeks, groups were sampled as described above.

\section{Cortisol RIA}

Cortisol was measured by RIA as described by Balm and colleagues (1998), using a commercial antiserum
(Bioclinical Services Ltd, Cardiff, UK). All constituents were in phosphate-EDTA buffer $\left(0.05 \mathrm{M} \mathrm{Na}_{2} \mathrm{HPO}_{4}\right.$, 0.01 $\mathrm{M} \mathrm{Na} \mathrm{Na}_{2}$ EDTA and 0.003 $\mathrm{M} \mathrm{NaN_{3 }}$ ). Standards or unknowns $(10 \mu \mathrm{l})$ in RIA buffer (phosphate-EDTA buffer containing $0 \cdot 1 \% 8$-anilino-1-naphthalenesulfonic acid and $0 \cdot 1 \%(\mathrm{w} / \mathrm{v})$ bovine $\gamma$-globulin) were incubated with $100 \mu \mathrm{l}$ antiserum (in RIA buffer containing 0.2\% normal rabbit serum) for $4 \mathrm{~h}$. Samples were incubated overnight with $100 \mu$ l iodinated cortisol (2000 d.p.m.; Amersham Nederland BV, 's Hertogenbosch, The Netherlands). Bound and free hormone were separated by adding $1 \mathrm{ml}$ ice-cold precipitation buffer (phosphate-EDTA buffer containing $2 \%(\mathrm{w} / \mathrm{v}) \mathrm{BSA}$ and $5 \%(\mathrm{w} / \mathrm{v})$ polyethylene glycol). The tubes were centrifuged at $4{ }^{\circ} \mathrm{C}(2000 \mathrm{~g}$, $20 \mathrm{~min}$ ), the supernatants removed, and counted in a gamma counter (1272 clinigamma; LKB Wallac, Turku, Finland).

\section{Statistical analysis}

In all experiments, differences among groups were assessed by one-way ANOVA. Subsequently, significance of differences between mean values was tested with the Tukey multiple comparison test. Statistical significance was accepted at $P<0 \cdot 05$. Values are expressed as means \pm s.E.M.

\section{Interassay variation}

The reproducibility of the CE-LIF method was assessed by determination of the interassay variation on nine consecutive experimental days. A 100 bp ladder was used as both standard and size control for the digested products. The integrated peak areas of this standard $100 \mathrm{bp}$ ladder were calculated for six peaks as a percentage of the total (see Table 1). The S.E.M. was less then $6 \%$ of the mean peak area for all peaks. Proceeding from the smaller than $6 \%$ interassay error variation, we conclude that this procedure is valid.

\section{Results}

Using RT-PCR, we were able to demonstrate the expression of two POMC mRNAs in the pituitary gland of a single fish (Fig. 1). After cloning of the two POMC mRNAs, one single primer set was selected for the amplification of both mRNAs by RT-PCR. Digestion with the restriction enzymes PvuII and SacI allowed discrimination between POMC-I and POMC-II. We found a difference in the POMC-I:POMC-II mRNA ratio between strains. Furthermore, we showed that the ratio was independent of the number of PCR cycles (Fig. 2). PCR products were quantified by integrating the peak areas measured by CE-LIF (Fig. 3). The reproducibility of the CE-LIF method was assessed by interassay variation, and the S.E.M. was $1 \cdot 8 \%$ or less (Table 1). 


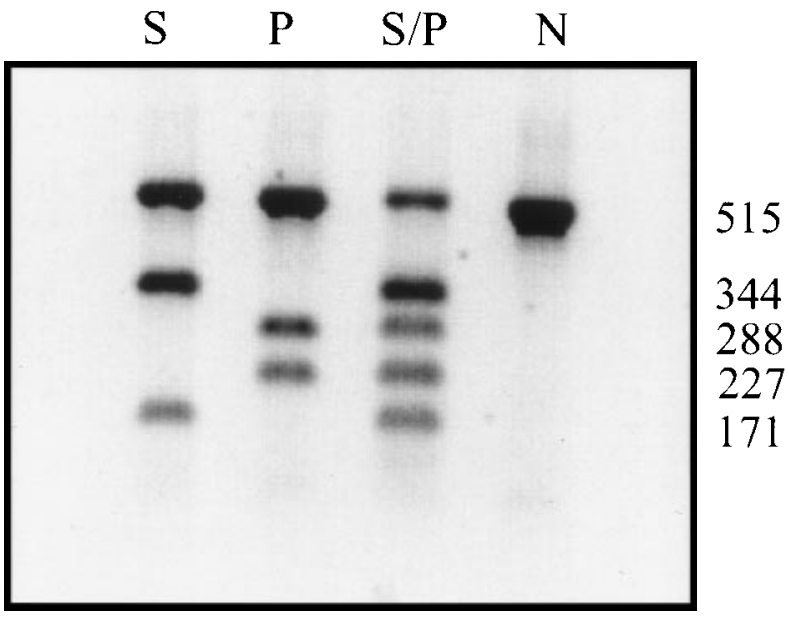

Figure 1 Digestion patterns of POMC-I and POMC-II RT-PCR products. RT-PCR products generated with carp POMC primers were digested for $3 \mathrm{~h}$ at $37^{\circ} \mathrm{C}$. All samples were derived from pituitary mRNA. Lane $\mathrm{S}$, digested with Sacl; lane $\mathrm{P}$, digested with Pvull; lane S/P, digested with Sacl and Pvull; lane N, not digested. CDNAs were fractionated on a $2 \%$ agarose gel and an inverted scan of the gel is shown. Molecular masses (Da) of the intact and digested products are given on the right.

To test whether POMC mRNA expression is straindependent, we determined the POMC-I:POMC-II ratio in the isogenic carp strains $\mathrm{E} 20 \times \mathrm{R} 8, \mathrm{R} 3 \times \mathrm{R} 8, \mathrm{E} 4$ and E4 $\times$ R3R8, and the wild-type carp. Percentage POMC-I mRNA expression in these carp, all kept at $24{ }^{\circ} \mathrm{C}$, is shown in Fig. 4. The POMC-I:POMC-II ratio was 1:1 for the wild type fish, 1:1.9 for strain E4 $\times$ R 3R8, 1:3.2 for strain E20 $\times \mathrm{R} 8,1: 3 \cdot 2$ for strain $\mathrm{E} 4$, and 1:5 4 for strain R3 $\times$ R8.

Furthermore, POMC mRNA expression in fish acclimated to different ambient temperatures $(15,24$ or $29^{\circ} \mathrm{C}$ ) was studied in strain E20 $\times$ R8. A significant increase in POMC-I mRNA expression was found in the fish acclimated to $15{ }^{\circ} \mathrm{C}$ ambient temperature, compared

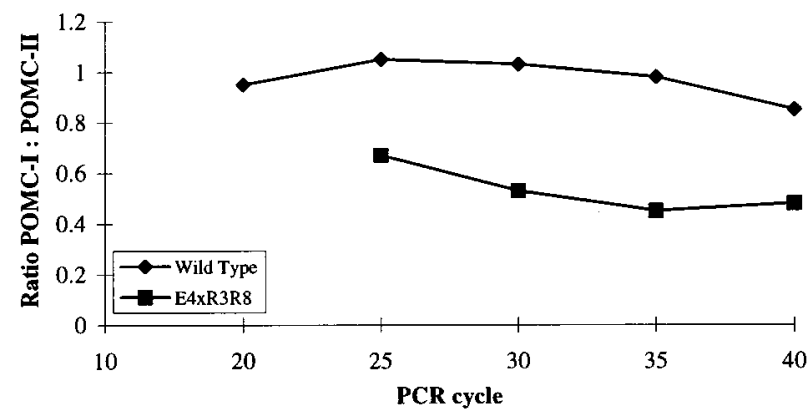

Figure 2 POMC mRNA expression during PCR amplification. Measurement of the POMC-I:POMC-II ratio during PCR amplification. PCR was performed in separate tubes for different numbers of cycles. PCR products were digested with Sacl and Pvull and quantified by CE-LIF. The ratio was calculated by dividing the integrated peak areas of POMC-I by POMC-II.

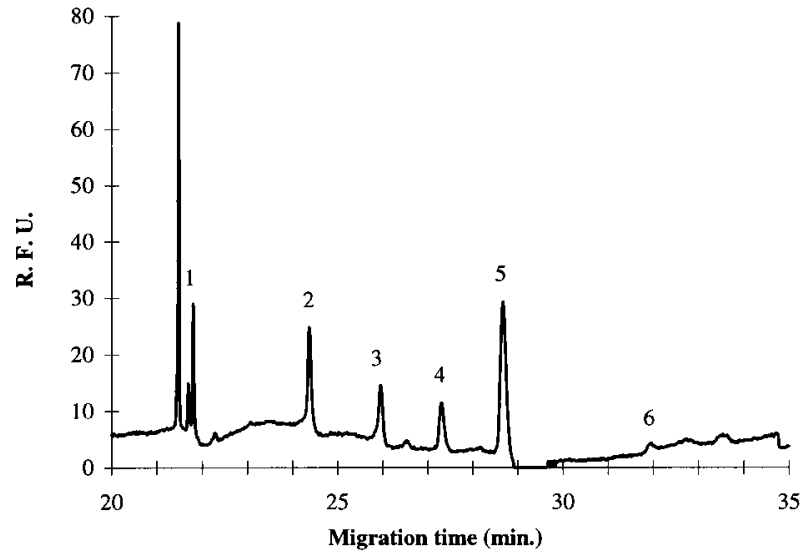

Figure 3 Quantification of digested RT-PCR products by CE-LIF. Separation of POMC Sacl/Pvull digest by CE with the detection of TO-PRO-3 complexes by LIF. Relative fluorescence units (R.F.U.) were detected at excitation and emission wavelengths of 642 and $660 \mathrm{~nm}$ respectively. Peak 1 , PCR primers; peaks 2 and 5, POMC-II; peaks 3 and 4, POMC-I; peak 6, undigested POMC. The POMC ratio was calculated by dividing the integrated areas of POMC-I (peaks 3 and 4) by POMC-II (peaks 2 and 5).

with those acclimated to 24 and $29^{\circ} \mathrm{C}$ (Fig. 4). The POMC-I:POMC-II ratio changed in favour of POMC-I from $1: 3 \cdot 2$ for fish kept at $24{ }^{\circ} \mathrm{C}$ to $1: 1 \cdot 2$ in fish adapted to $15{ }^{\circ} \mathrm{C}$.

Plasma cortisol levels in fish adapted to ambient temperatures of 15,24 or $29^{\circ} \mathrm{C}$ were significantly different (Fig. 5).

Next, short-term effects on POMC mRNA expression were studied in the isogenic strain E4 $\times$ R 3R 8. In these carp, a POMC-I:POMC-II ratio of 1:1.9 was found. At time points up to $5 \mathrm{~h}$ after the fish experienced a fall in temperature of $9{ }^{\circ} \mathrm{C}$, POMC mRNA expression in the pituitary gland was measured. At $3 \mathrm{~h}$ after the rapid drop in temperature, percentage POMC-I had decreased significantly $(P<0 \cdot 02)$, resulting in a change in the POMC-I: POMC-II mRNA ratio at the expense of POMC-I from $1: 1.9$ at $t=0$ to $1: 4 \cdot 2$ at $t=3 \mathrm{~h}$, and increased in favour of POMC-I again to $1: 1.7$ at $t=5 \mathrm{~h}$ (the temperature returned to $24{ }^{\circ} \mathrm{C}$ at between 3 and 5 h; Fig. 6).

\section{Discussion}

In the present study RT-PCR combined with CE-LIF allowed us to quantify differences in expression of closely related POMC genes (93.5\% nucleotide sequence identity (Arends et al. 1998) from a tetraploid carp. The fact that no digestion of POMC-I by PvuII and no digestion of POMC-II by SacI occurred indicates the specificity of the enzymes used. As only one primer set was used in the PCR, irregular competition between competitive cDNAs was avoided and the suggested use of an internal standard in quantitative PCR (Siebert \& Larrick 1993, Riedy et al. 
Table 1 Day to day (interassay) variation of a $100 \mathrm{bp}$ cDNA ladder

Day to day variation $(n=9)$

\begin{tabular}{lllllllll}
\cline { 2 - 7 } Size (bp) & 100 & 200 & 300 & 400 & 500 & 600 & 1400 & 2200 \\
Mean peak area (\%) & $12 \cdot 5$ & $3 \cdot 6$ & $3 \cdot 2$ & $2 \cdot 9$ & $2 \cdot 7$ & $2 \cdot 4$ & $2 \cdot 6$ & $70 \cdot 2$ \\
S.E.M. & $1 \cdot 1$ & $0 \cdot 3$ & $0 \cdot 2$ & $0 \cdot 2$ & $0 \cdot 2$ & $0 \cdot 2$ & $0 \cdot 1$ & $1 \cdot 8$
\end{tabular}

Integrated peak areas were calculated as percentage of a total of six peaks of a $100 \mathrm{bp}$ cDNA ladder. Mean \pm S.E.M. peak area was calculated from nine experimental days.

1995) was thus not necessary. In PCR, exponential amplification of the cDNA takes place. For the PCR quantification, only the linear part of the reaction reflects the initial ratio of mRNAs. Indeed at between 20 and 40 cycles, the POMC-I:POMC-II ratio appeared to be independent of the number of PCR cycles. To avoid exhaustion of one of the PCR ingredients, 30 cycles were chosen to quantify the ratio of the two POMC mRNAs. With this method the ratio between the two POMC mRNAs could reproducibly be assessed and we consider the ratio to be an appropriate index of differential gene expression. Our method allows quantification of the ratio of differentially expressed genes and not of absolute amounts mRNA. For quantification of total mRNA expression a method using a control gene, e.g. that of $\beta_{2}$-microglobulin, should be used (Murphy et al. 1990).

The finding of a POMC-I:POMC-II mRNA ratio of $1: 1$ in wild-type carp points to an unbiased duplication of the POMC gene. However, to our surprise the ratio deviated significantly from 1 in the isogenic strains, from 1:5.4 for strain R3 $\times$ R 8 to $1: 1.9$ for strain $\mathrm{E} 4 \times \mathrm{R} 3 \mathrm{R} 8$.

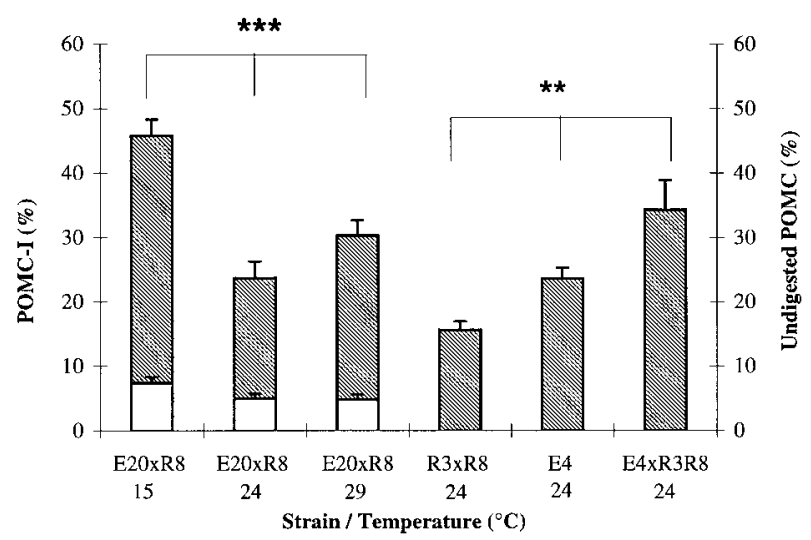

Figure 4 POMC mRNA expression in temperature-adapted carp and in different strains. Percentage POMC-I mRNA expression in the isogenic carp strains $\mathrm{E} 20 \times \mathrm{R} 8(n=8), \mathrm{R} 3 \times \mathrm{R} 8(n=4), \mathrm{E} 4(n=4)$ and E4 $\times$ R3R8 $(n=5)$ is shown as closed bars. Open bars indicate the percentage of POMC not digested in strain E20 $\times$ R8; in the other groups the digestion was $100 \%$. Values are expressed as means \pm S.E.M. A significant decrease in POMC-I mRNA expression $\left.{ }^{(* *}\right)$ was found between the $15{ }^{\circ} \mathrm{C}$ - and $24{ }^{\circ} \mathrm{C}$ - and $29{ }^{\circ} \mathrm{C}$-adapted fish $(P<0 \cdot 001)$. Furthermore, the percentage POMC-I differed significantly ${ }^{* *}$ ) between the strains R3 $\times$ R8, E4 and E4 $\times$ R3R8 $(P<0 \cdot 01)$.
This may indicate that, as a result of polymorphism, annealing of one of the primers was inhibited, thereby introducing a strain-dependent POMC mRNA ratio. However, we think that polymorphism cannot be the cause of the ratio shift in carp. One could argue that strain-dependent differential POMC mRNA expression was introduced during the gynogenetic reproduction of these isogenic carp, as the result of embryonic damage caused by the chromosome manipulation treatment (Bongers et al. 1997). However, all these strains have been tested for microsatellites and proven to be homozygous, indicating that duplicate sets of all genes are present in these fish (Crooijmans et al. 1997).

We tested the hypothesis that ambient temperature may alter the POMC mRNA ratio. A significantly altered POMC mRNA ratio in favour of POMC-I was found in carp (strain E20 $\times$ R8) adapted to $15{ }^{\circ} \mathrm{C}$ compared with those adapted to 24 and $29^{\circ} \mathrm{C}$. The digestion of the PCR product in this experiment was not $100 \%$, but the amount of undigested PCR product was less than $7 \%$ and could not be responsible for the shift in ratio. It is not known whether this ratio shift was caused by increased expression of POMC-I or decreased expression of POMC-II or a combination of the two. It is known that environmental temperature directly influences basal constitutive hormone release (Fine et al. 1996, Lin et al. 1996), but both the wild-type and isogenic strains R $3 \times \mathrm{R} 8$ and $\mathrm{E} 4 \times \mathrm{R} 3 \mathrm{R} 8$ were kept at $24^{\circ} \mathrm{C}$, which would exclude upregulation of the release as a result of increased metabolic activity. We

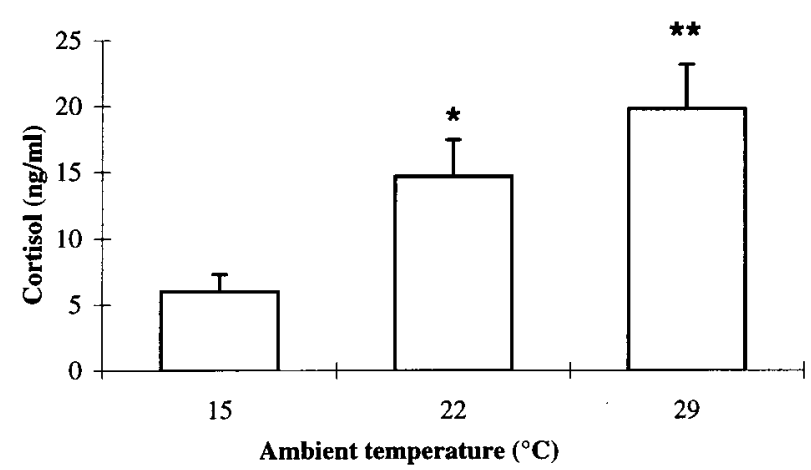

Figure 5 Cortisol levels in carp adapted to different ambient temperatures for at least 8 weeks. Plasma cortisol levels were significantly different $\left({ }^{*} P<0 \cdot 05,{ }^{* *} P<0 \cdot 01, n=17\right)$. 


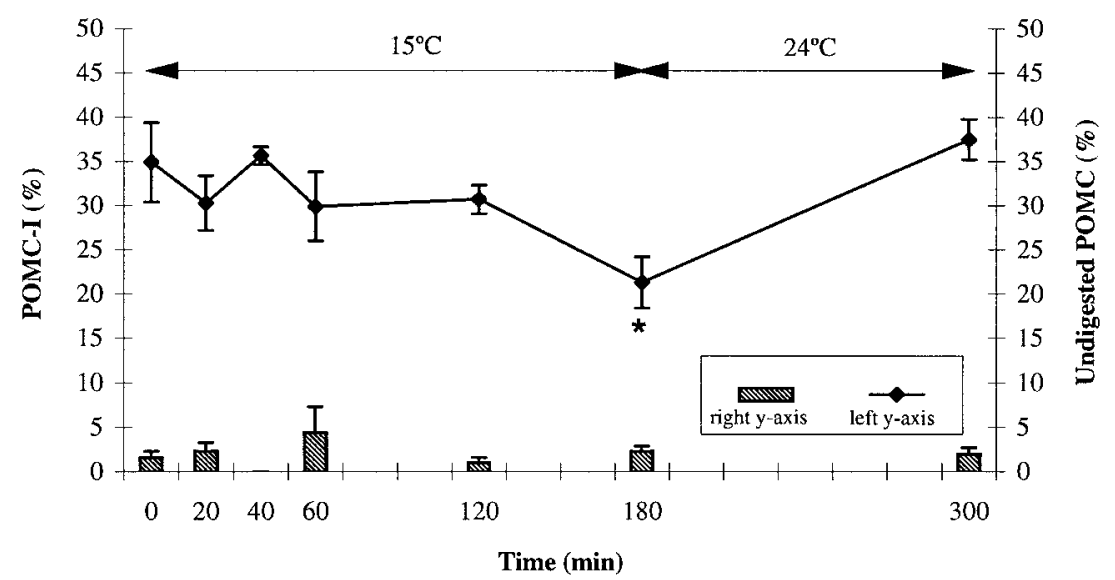

Figure 6 POMC-I mRNA expression during temperature-induced stress. Percentage POMC-I mRNA expression in the isogenic carp strain E4 $\times$ R3R8 after a temperature shock of $-9{ }^{\circ} \mathrm{C}$ (left $y$-axis, $n=5$ ). Bars represent percentage of POMC not digested (right $y$-axis). Values are expressed as means \pm S.E.M. A significant decrease $\left(^{*}\right)$ in POMC-I mRNA expression was found at $t=180 \mathrm{~min}(P<0 \cdot 02)$.

measured plasma cortisol levels to check whether the environmental temperature had evoked a stress response, because in salmonid fishes temperature shock potentiates the stress response to handling and confinement (Sumpter et al. 1985, 1986). A significant effect of ambient temperature on basal cortisol secretion was found. However, plasma cortisol levels were less than $20 \mathrm{ng} / \mathrm{ml}$, indicating that the fish were probably not stressed and were well adapted to the different ambient temperatures. These results therefore indicate that ambient temperature alters the quality (preference for either POMC-I mRNA or POMC-II mRNA) of the message rather than the quantity.

We then tested the hypothesis that a rapid drop in ambient temperature could evoke a stress response and induce differential expression of the the two POMC mRNAs in an experiment in which fish were exposed to a rapid drop in temperature of $9{ }^{\circ} \mathrm{C}$, which evokes a time-dependent cortisol response. These fish were probably stressed by the treatment because, in a similar experiment, we found that plasma cortisol levels were elevated, up to 6 times the control level, 20 min after the start of the experiment and remained elevated until the end of the temperature shock treatment $(t=3 \mathrm{~h})$, indicating that this drop in temperature was a stressful event for the fish. At time point $t=5 \mathrm{~h}(2 \mathrm{~h}$ after the temperature had returned to $24^{\circ} \mathrm{C}$ ), plasma cortisol levels were back to control levels (M Tanck, J Komen and S E Wendelaar Bonga, unpublished observations). We found a significantly altered POMC-I:POMC-II mRNA ratio at the expense of POMC-I $3 \mathrm{~h}$ after the onset of the rapid temperature drop, indicating that the fall in temperature increased POMC mRNA transcription and that this newly transcribed POMC mRNA was mainly POMC-II. This is in agreement with mammalian literature, in which a stress-induced increase in POMC mRNA expression has been demonstrated in the pituitary gland of rats (Hollt et al. 1986, Shiomi et al. 1986). Our results indicate that in carp a control mechanism for the regulation of POMC mRNA expression is activated during temperatureinduced stress. However, as absolute amounts of mRNA were not measured, differences in POMC-I and POMC-II mRNA clearance could also explain the shift in ratio. The amount of undigested POMC mRNA in this experiment was less then $5 \%$ and could not be responsible for this ratio shift. We therefore conclude that the observed differential expression is induced by the temperature shock acting as a stressor. The mechanism for the activation of this stress-induced differential expression is not known, but differential affinity of transcription factors for the promoters of the two POMC genes is a possible candidate.

Although it has been known for many years that two POMCs are expressed in tetraploid animals (Kawauchi 1983, Martens et al. 1985, Salbert et al. 1992), there is still little evidence for any biological significance of the presence of two gene transcripts. In one report on rainbow trout, POMC-A and POMC-B cDNAs were cloned (Salbert et al. 1992), but the expression of POMC-A, but not POMC-B, in hypothalamic neurones of sexually immature fish was found. Furthermore, in the amphibian Xenopus laevis, differences in processing of end products of POMC-A and POMC-B could be detected in animals adapted to black and white backgrounds (Van Strien et al. 1996). Our results provide the first evidence for the differential expression of two POMC mRNAs during temperature-induced stress and in response to different ambient temperatures in the tetraploid carp.

It is still not known in which cells this POMC ratio shift occurs: the corticotropic cells of the pars distalis or the 
melanotropic cells of the pars intermedia. In carp, the two POMC molecules produce the same type of $\alpha-\mathrm{MSH}$ and $\beta$-endorphin peptides, but two different types of ACTH and $\beta$-MSH (Arends et al. 1998). As the rapid drop in temperature described here induces an $\alpha$-MSHindependent rise in cortisol ( $\mathrm{S} \mathrm{E}$ Wendelaar Bonga, unpublished observations), we hypothesize that the corticotropic cells are involved in this response. As amino acid substitutions occur in the ACTH peptide but not in $\alpha-\mathrm{MSH}$ and endorphins, differential POMC expression in the corticotrophs may well be functional. RIAs are currently being set up to study these different POMCderived peptides in plasma. Future studies will address the questions of whether the ratio of the POMC mRNAs affects the cortisol release, and whether cortisol feedback regulates the POMC gene and thereby affects the ratio of the POMC mRNAs.

\section{Acknowledgements}

This study was partially supported by SLW 805-33101-P. The authors gratefully acknowledge Dr J Komen and Mr M Tanck (Department of Fish Culture, Agricultural University of Wageningen, The Netherlands) for the generous gift of isogenic carp strains, $\mathrm{Mr} \mathrm{E}$ van den Burg for critically reading the manuscript and $\mathrm{Mr} \mathrm{T}$ Spanings for animal care.

\section{References}

Abo HS \& Hanke W 1984 The significance of cortisol for osmoregulation in carp (Cyprinus carpio) and tilapia (Sarotherodon mossambicus). General and Comparative Endocrinology 54 409-417.

Arends RJ, Vermeer H, Martens GJM, Wendelaar Bonga SE \& Flik G 1998 Cloning and expression of two proopiomelanocortin mRNAs in the common carp (Cyprinus carpio L.). Molecular and Cellular Endocrinology (In Press).

Balm PHM, Haenen HEMG \& Wendelaar Bonga SE 1994 Regulation of interrenal function in freshwater and seawater adapted tilapia (Oreochromis mossambicus). Fish Physiology and Biochemistry 14 37-47.

Balm PHM, Rentier-Delrue F, Rand-Weaver M \& Martial JA 1998 Recombinant rainbow trout somatolactin (SL) counteracts stress-associated hypochloremia. Molecular and Cellular Endocrinology (In Press).

Bongers ABJ, Benayed MZ, Doulabi BZ, Komen J \& Richter CJJ 1997 Origin of variation in isogenic, gynogenetic, and androgenetic strains of common carp, Cyprinus carpio. Journal of Experimental Zoology 277 72-79.

Crooijmans R, Bierbooms VAF, Komen J, van der Poel JJ \& Groenen MAM 1997 Microsatellite markers in common carp (Cyprinus carpio L). Animal Genetics 28 129-134.

Fasco MJ, Treanor CP, Spivack S, Figge HL \& Kaminsky LS 1995 Quantitative RNA-polymerase chain reaction-DNA analysis by capillary electrophoresis and laser-scanning fluorescence. Analytical Biochemistry 224 140-147.

Fine M, Zilberg D, Cohen Z, Degani G, Moav B \& Gertler A 1996 The effect of dietary protein level, water temperature and growth hormone administration on growth and metabolism in the common carp (Cyprinus carpio). Comparative Biochemistry and Physiology 114A $35-42$.
Gupta OP \& Hanke W 1982 The effects of osmotic stressors on the stenohaline carp (Cyprinus carpio). Comparative Biochemistry and Physiology 71A 165-173.

Hollt V, Przewlocki R, Haarmann I, Almeida OF, Kley N, Millan MJ \& Herz A 1986 Stress-induced alterations in the levels of messenger RNA coding for proopiomelanocortin and prolactin in rat pituitary. Neuroendocrinology 43 277-282.

Kawauchi H 1983 Chemistry of proopiocortin-related peptides in the salmon pituitary. Archives of Biochemistry and Biophysics 227 343-350.

Larhammar D \& Risinger C 1993 Molecular genetic aspects of tetraploidy in the common carp Cyprinus carpio. Molecular Phylogenetics and Evolution 3 59-68.

Le Morvan-Rocher C, Troutaud D \& Deschaux P 1995 Effects of temperature on carp leukocyte mitogen-induced proliferation and nonspecific cytotoxic activity. Developmental and Comparative Immunology 19 87-95.

Lin XW, Lin HR \& Peter RE 1996 Direct influences of temperature on gonadotropin-II release from perifused pituitary fragments of common carp (Cyprinus carpio L.) in vitro. Comparative Biochemistry and Physiology 114A 341-347.

Mancera JM, Perez-Figares JM \& Fernandez-Llebrez P 1994 Effect of cortisol on brackish water adaptation in the euryhaline gilthead sea bream (Sparus aurata L.). Comparative Biochemistry and Physiology 107A 397-402.

Martens GJM, Civelli O \& Herbert E 1985 Nucleotide sequence of cloned cDNA for proopiomelanocortin in the amphibian Xenopus laevis. Journal of Biological Chemistry 260 13685-13689.

Murphy LD, Herzog CE, Rudick JB, Fojo AT \& Bates SE 1990 Use of the polymerase chain reaction in the quantification of mdr-1 gene expression. Biochemistry 29 10351-10356.

Riedy MC, Timm EA \& Stewart CC 1995 Quantitative RT-PCR for measuring gene expression. Biotechniques 18 70-76.

Salbert G, Chauveau I, Bonnec G, Valotaire Y \& Jego P 1992 One of the two trout proopiomelanocortin messenger RNAs potentially encodes new peptides. Molecular Endocrinology 6 1605-1613.

Shiomi H, Watson SJ, Kelsey JE \& Akil H 1986 Pretranslational and posttranslational mechanisms for regulating beta-endorphinadrenocorticotropin of the anterior pituitary lobe. Endocrinology 119 1793-1799.

Siebert PD \& Larrick JW 1993 PCR MIMICS: competitive DNA fragments for use as internal standards in quantitative PCR. Biotechniques 14 244-249.

Sumpter JP, Pickering AD \& Pottinger TG 1985 Stress-induced elevation of plasma $\alpha-\mathrm{MSH}$ and endorphin in brown trout, Salmo trutta L. General and Comparative Endocrinology 59 257-265.

Sumpter JP, Dye HM \& Benfey TJ 1986 The effects of stress on plasma ACTH, $\alpha-\mathrm{MSH}$, and cortisol levels in salmonid fishes. General and Comparative Endocrinology 62 377-385.

Ultsch GR, Ott ME \& Heisler N 1981 Acid-base and electrolyte status in carp (Cyprinus carpio) exposed to low environmental $\mathrm{pH}$. Journal of Experimental Biology 93 65-80.

Uyeno T \& Smith GR 1972 Tetraploid origin of the karyotype of catostomid fishes. Science 175 644-646.

Van Strien FJC, Jespersen S, van-der-Greef J, Jenks BG \& Roubos EW 1996 Identification of POMC processing products in single melanotrope cells by matrix-assisted laser desorption/ ionisation mass spectrometry. FEBS Letters 379 165-170.

Weijts FAA, Verburg-van Kemenade BML, Flik G, van Muiswinkel WB \& Wendelaar Bonga SE 1997 Immune-endocrine interactions in fish: effects of cortisol and corticosterone on apoptosis of carp lymphocytes. Brain Behaviour and Immunity 11 95-105.

Wendelaar Bonga SE 1997 The stress response in fish. Physiological Reviews 77 591-625.

Won SJ \& Lin MT 1995 Thermal stresses reduce natural killer cell cytotoxicity. Journal of Applied Physiology 79 732-737.

Received 2 March 1998

Accepted 26 May 1998 